УДК 316:3:72

DOI https://doi.org/10.32840/2707-9147.2019.84.2

H. K. MIXHO

\title{
ТРАНСФОРМАЦІЯ АРХІТЕКТУРНИХ ФОРМ МІСТА ПІД ВПЛИВОМ ЗМІН СОЦІОІСТОРИЧНИХ УМОВ
}

Основна увага в иій статті зосереджена на визначенні характеру змін архітектурних форм в міському просторі залежно від руху соиіоісторичних умов розвитку суспільства. Налагоджено актуалізачію наукового інтересу для вивчення місия та ролі архітектурних об'єктів у площині сучасності. Виокремлено основні наукові вектори дослідження проблемного поля соиіології архітектури. Підкреслено, щзо зміни, які відбуваються в політичному та культурному полі, відповідно впливають на організацію простору міста, зокрема й архітектурні ландшафти. В історії украӥнського суспільства відбулися кардинальні зрушення в переходах від імперського до радянського ідеологічного дискурсу сучасного незалежного украӥнця, щчо, отже, вплинуло на символічне маркування просторових явищ та містобудування. На основі запропонованих У. Еко екологічно-архітектурних класифікаційних кодів (синтаксис - код, щу належить до техніки будівництва; семантичний-артикуляиія архітектурних елементів, артикуляція типів конструкиій) та в результаті проведеного авторського дослідження методом візуального аналізу на прикладі міста Дніпра було зафіксовано специфічні та типові характеристики міського простору - від катеринославського модернового стилю до індустріального домінування, конструктивізму, постмодернізму, ефектів «макдональдизації», начіонального романтизму тощьо.

Архітектурна форма будівель радянського періоду представлена "Сталінками», "Хрущовкою» та панельними багатоквартирними будинками. Зазначається, щзо ия класифікачія будівель синтагматично відображає найбільш значущі архітектурні об'єкти міста. Значна увага приділясться особливостям виготовлення та представлення архітектурних кодів у сучасному украӥнському місті. Зазначається, щчо зрушення в організації організаційної політики міського простору, велика кількість різноманітних тенденцій архітектурних моделей, зміна соціокультурних та сочіально-економічних умов існування украӥнського суспільства суттєво вплинули на візуальний та символічний імідж міст Украӥни. Звертається увага на зникнення ідейних рамок розвитку міста та включення національно-патріотичного символізму та ідеологічних кодів в архітектурний ландшафт міста. Вказане відображення в архітектурному ландшафті та публічних просторах тенденція міста «макдональдизації» (у широкому та вузькому розумінні). Зафіксовані поява гібридних форм архітектурних ландшафтів, досить дивне поєднання стилів Катеринослава Модерна, радянського конструктивізму, постмодернізму, хай-тек тошо.

Ключові слова: місто, міський простір, архітектурний об'єкт, архітектурний ландмафт, архітектурна форма, візуальний код, публічний простір.

(C) Мiхно Н. К., 2019 
Міське середовище для сприйняття суб'єкта існує не само по собі, а має реляційний характер: всі предмети середовища існують як елементи подій, які є значущими для суб'єкта сприйняття. Предмети міського середовища існують як елементи життєвого світу містян: вони свідчать, нагадують, вказують на те, що було, є або буде (має бути). Оскільки події як значуща система дій існують в смисловому контексті, то за його втрати окремі фрагменти міського середовища втрачають свою виразність або навіть зникають для сприйняття. Дуже влучно підкреслює важливість вивчення архітектури соціологами В. Вахштайн. Зокрема, він відмічає, що за логікою, соціологія архітектури повинна бути невіддільною частиною соціології міста. Але ось парадокс: міська соціологія як самостійна дослідницька область існує 3 кінця XIX століття, вона майже ровесниця дисципліни загалом. Місто спочатку входило в число привілейованих об'єктів соціологічного розгляду поряд 3 технікою, господарством і релігією. 3 усіх класиків соціологічної науки про місто не писав тільки Е. Дюркгейм. При цьому архітектурні об'єкти - саме як окремий дослідний феномен дуже довгий час не вивчалися соціологами [4].

Місто загалом потрапляє у фокус уваги науковців вже досить тривалий час: від класичного періоду теоретизування (М. Вебер, Г. Зіммель, $\Phi$. Тьоніс та ін.) до численних сучасних наукових робіт. Вагомий внесок у розвиток міських досліджень зробили історико-культурологічні, соціологічні та урбаністичні теорії у другій половині ХХ століття. До них належать роботи Ж. Бодрійяра «Місто і ненависть», Дж. Логана “Тhe City as a Growth Machine”, П. Бурд’є «Соціальний простір: поля і практики», К. Лінча «Креативне місто», Л. Мамфорда «Міф машини», Д. Джекобс «Смерть і життя великих американських міст» [6] та ряд інших. До обговорення проблематики архітектури зверталися фахівці з соціології культури (М. Макропулоса, И. Фішер, В. Прігге), соціології міста (Г. Шуберт, Б. Шеферс, Х. Хойзерман, Й. Дангшат, В. Сібель, Х. Боденшатц). Також варто відмітити, що, на думку Х. Делітца, цікавий аспект порушувався в роботах С. Сассен, К. Дёрхёфер, С. Франк, К. Вереш, Ф. Будон.

За минулі десятиліття сформувалася російська школа урбаністики та групи дослідників, працюючих в межах соціології міста, як-от: В. Вахштайн, В. Глазичев, О. Трубіна, О. Запорожец, Н. Самутіна, Г. Ревзін, Д. Візгалов, О. Паченков, Г. Осадча, В. Ільїн, Я. Рощина та інші. У галузі соціології міста працює і низка відомих українських вчених, зокрема йдеться про О. Макеєва, С. Матяш, I. Прибиткову, В. Бєлоусова, О. Міхеєву, О. Мусієздова, А. Петренко-Лисак, В. Середу, Ю. Сороку, Л. Малес, Д. Судіна та ряд інших. Хоча місто як об'єкт наукових інтенцій є цікавим для українських соціологів, але в той же час проблематика вивчення архітектурного простору міста сьогодні є досить обмеженою.

Метою роботи є окреслення актуальності вивчення архітектурного простору міста соціологічною наукою, а також визначення модусів 
трансформації та модифікації архітектурних форм під впливом зміни історичного контексту розвитку суспільства.

Архітектурний об'єкт чинить істотний світоглядний вплив на суспільну свідомість, відповідно, соціокультурна функція архітектурного об'єкту проявляється в тому, що він є в стислому виді просторовою моделлю міста. Як відмічає М. Назарова, основною соціокультурною функцією архітектури є трансляція просторової моделі світоустрою у конкретних соціально-історичних ситуаціях, тобто розширення i відтворення архітектурного простору $є$ безперервним процесом створення форм через накопичення культурно-закріплених просторових моделей, представлених в архітектурних об'єктах [9].

У макромасштабі історичного часу архітектура фіксує певні стадії розвитку суспільства, його історії, стає матеріалізованою формою колективної пам'яті. Чинник часу визначає багатовимірність архітектури, іiі просторово-часову єдність (хронотоп). Відомий дослідник міської архітектури О. Іконніков підкреслює, що архітектура формує не лише матеріальні оболонки для процесів життєдіяльності, але і «тексти» повідомлень, закодовані специфічною мовою форм, дозволяючи людям орієнтуватися у фізичному i культурному просторі і закріплюючи системи ідей і цінностей [7].

Своєю чергою Ю. Лотман вважав, що архітектурний простір живе подвійним семіотичним життям: «3 одного боку, він моделює універсум: структура світу побудованого і обжитого переноситься на весь світ загалом. 3 іншого боку, він моделюється універсумом: світ, що створюється людиною, відтворює ії уявлення про глобальну структуру світу» [8].

Так, відомий вже нам У. Еко приділив багато уваги аналізу семіології архітектури. Під час семіологічного розгляду вчений бачить в архітектурних спорудах не лише об'єкти, що характеризуються виконуваною ними функцією, але і об’єкти комунікації. Архітектура представляється сукупністю знаків і символів, які денотують (означають) утилітарні функції споруди і конотують його символічний сенс. У. Еко говорить про «функціональну» денотацію і «символічну» конотацію.

Відштовхуючись від різних «семантичних» або «семіологічних» прочитань архітектури, У. Еко пропонує таку класифікацію архітектурних кодів [14]:

1. Синтаксичні коди: характерний у цьому сенсі код відсилає до техніки будівництва. Архітектурна форма може включати: балки, стелі, перекриття, консолі, арки, пілястри, бетонні клітини. Тут немає ні вказівки на функцію, ні віднесення до простору, який денотується діє тільки структурна логіка, що створює умови для подальшої просторової денотації.

\section{2. Семантичні коди:}

1. артикуляція архітектурних елементів: елементів, що означають первинні функції - дах, балкон, слухове вікно, купол, сходи, вікно; 
елементів, які означають вторинні «символічні» функції, - метопа, фронтон, колона, тимпан; елементів, що означають функціональне призначення і відображають «ідеологію проживання», - салон, частина житла, де проходить день, проходить ніч, вітальня, їдальня;

2. артикуляція за типами споруд: соціальним: лікарня, дача, школа, замок, палац, вокзал; просторовим: храм на круглій основі, з основою у вигляді грецького хреста, «відкритий» план, лабіринт.

У такому разі коди, про які говорить У. Еко, не що інше, як іконічні, стилістичні або риторичні лексікоди. Тобто з комунікативної точки зору архітектура є однією з форм масової комунікації.

Як наочний матеріал для аналізу дискурсу історичної пам'яті у сучасному українському місті пропонується зафіксувати «тексти» архітектурних об'єктів м. Дніпра. Будь-яка національна чи імперська ідея чи ідеологія впроваджувалися через витвори мистецтва, передусім через архітектуру і містобудування, оскільки людина може не читати книг, не ходити в музеї і театри, але місто і будівлі, що його утворюють, бачить щодня. В усіх містах у різні історичні періоди з'являються ансамблі, що презентують домінуючі змістовні коди.

Візуальний код Дніпра представлений симбіозом архітектурних стилів, які презентують змістовні символічні коди, які є характерними для різних історичних етапів існування міста: умовно ми можемо виділити три періоди, що представляють різне ідеологічне навантаження формування міського простору, - імперський, радянський, незалежної української держави. Спробуємо прояснити логіку організації архітектурних ландшафтів міста в зазначені періоди.

Період перебування у складі Російської імперій.

Характерною особливістю модерну у Російській імперії, на відміну від Свропи, де була сформована його ідеологія, $є$ те, що він поширювався на iї території дуже швидко і скоріше як явище архітектурної моди, ніж як усвідомлений «новий стиль», альтернативний еклектиці. Модерн реалізовував популярну на той час програмну творчу концепцію «синтезу промисловості і мистецтва», витягуючи з нових технічних можливостей більшу свободу в архітектурному формоутворенні: тепер можна було значно збільшити поверховість будівель, перекрити великі прольоти, урізноманітнити пластику об'ємів застосуванням підвішених еркерів, витіюватих за формою веж і дуже активного пластичного декору [5].

Радянський період містобудування.

Дослідник, які працюють у напряму вивчення особливостей містобудівних стратегій радянської епохи, зазначають, що для радянської архітектури мали велике значення теоретичні погляди Л. Корбюз'є. Архітектор підкреслював значення прямих вулиць (порядок дає свободу) і вважав важливим приведення сучасного міста 3 його хмарочосами до людського масштабу. Після детального опису життя свого ідеального міста автор як приватний приклад розглядає центр Парижу. 
Радянська архітектура у XX столітті розвивалася у тісній взаємодії з розвитком суспільства, відповідаючи на соціальні виклики і підкоряючись політичній владі. Тобто вона була певним продовженням соціальних технологій щодо побудови соціальних утопій або боротьби 3 ними. Так, С. Хан-Магомедов виділяє декілька періодів розвитку радянської архітектури: окрім авангарду, який активно існував близько 15 років, 20 років розвивався «сталінський ампір», а потім його змінив «хрущовський утилітаризм» [11; 12].

Якою ж є логіка організації архітектурних ландшафтів? Які змістовні «повідомлення» були покладені в основу? Передусім в індустріальному місті треба переміщати з роботи і на роботу величезні маси людей, чого раніше ніколи не було. Відповідно, проблема транспорту стає головною і визначає більшість планувальних рішень. Крім того, ці мільйони необхідно десь селити. На відміну від ремісників, купців, чиновників, для яких важливо щось про себе сказати фасадом власного будинку, маси, що заповнювали великі радянські індустріальні міста, не мають коренів, і в цьому відношенні абсолютно однакові. Люди втрачають індивідуальність, перетворюються на трудовий ресурс, для якого будується масове, стандартне житло. Неважливо, бараки це на першому етапі, казарми, спальні райони - головне, що усі живуть в однакових умовах [1].

Грунтовно проаналізоване смислове навантаження радянської архітектури представлено у публікаціях Л. Бачинської, яка підкреслює, що архітектура, яка була створена під тиском керівних органів, обіцяла світле майбутнє для трудящих, ідеї якого народ підхопив і сліпо у них повірив, створювала штучне середовище, що було носієм державної ідеології. Серед різних способів декоративності архітектури розглядуваного періоду головним, найбільш виразним, ясним і влучним було використання державної символіки у закладах і установах представницької архітектури і не тільки.

У зв’язку із завданнями, що були покладені на державну символіку, для неї обирали на фасадному полі найкраще 3 точки зору візуального сприйняття та композиції місце, що добре проглядалося на відповідній відстані. Державні символи використовували: 1) як ознаки, що свідчили про тип політичного режиму; 2) як матеріальні елементи штучного середовища, що фіксували ці ознаки і потребували від народу шани, поваги, милування (тому форма символів і зміст мусили бути гармонійними); 3) як ознаки, що формували таке штучне середовище, яке виховувало населення у дусі патріотизму, любові до своєї нації і держави; 4) символи праці формували суспільну свідомість, спрямовану на підкреслення важливості праці для розвитку держави і добробуту народу, навіть на підтримку і поширення ідеї радощів, які надає праця на суспільне благо [3].

Архітектурні форми житлових будинків представлені «сталінками», «хрущовками», панельними багатоповерхівками. Що у них 
особливого? Саме така класифікація будівель найбільш змістовно відображає синтагматичність архітектурних об'єктів у місті. Будівлі сталінського періоду здебільшого розташовані у центральній частині міста, у подальшому стають маркером статусності мешканців (соціальний, економічний капітал). Другим колом $є$ поширення будівель хрущовського періоду, які вирізняються маркером приналежності до робітничого класу. Третє коло забудови представлено збільшенням кількості масивів багатоповерхівок (з найбільшим рівнем одноманітності та уніфікації), з одночасним зменшенням «приватного сектору».

Так, масове будівництво соціального житла («хрущовок») чудово вкладалося в ідеологічну колею радянщини. Це було створення нового середовища для нової (радянської, звичайно) людини. Простота форми, широкі засклені поверхні, що дають багато світла, бетон і сучасні будматеріали створювали новий урбаністичний пейзаж, в якому людина мала все необхідне для життя (хоча б у мінімальному обсязі) [13]. У подальшому дана ідея була поглиблена у забудові «спальних районів» багатоповерхівками. Навколо панельних будинків були широкі двори. При цьому планувалися не лише житлові будівлі, а цілі квартали і райони, продумувалася інфраструктура. Радянські норми того часу були досить жорсткими: від будинку до дитячого садочка мало бути не більше 200 метрів, а до школи - 500. Будинки розташовували так, щоб дітям по дорозі до школи не треба було зайвий раз переходити вулицю. Поліклініки чи, приміром, спортивні секції, теж мали бути поруч.

Пострадянський період. Період незалежної української держави.

Зазначимо, що після розпаду СРСР поступово відбулися зрушення у політиці організації забудови міського простору, велика кількість різнопланових тенденцій в архітектурних взірцях, зміна соціокультурних та соціоекономічних умов існування українського суспільства суттєво вплинули на візуальний та символічний образ українських міст.

По-перше, варто звернути увагу на зникнення ідеологічних фреймів забудови території міста та інкорпорацію національно-патріотичної символіки й ідеологічних кодів в архітектурні ландшафти міста починаючи з 2014 року (завершення Революиії Гідності та початок військових дій на Сході Украӥни). Саме хронологічні рамки 2014 р. - по теперішній час можливо охарактеризувати як «національний романтизм» у міських просторах - насичення візуальних кодів, забарвлених у кольори національних символів, тенденції в оформленні рекламних кампаній з урахуванням національно-культурних артефактів, традиційних орнаментів тощо. Найвищого піку демонстрації національно-патріотичних почуттів набули в 2014-2015 pр. оформлення будинків національними кольорами та прапорами, поява національно-патріотичних графіті-дизайнів та інші.

По-друге, важливо зазначити відображення в архітектурних ландшафтах та публічних просторах міста тенденції «макдональдизації» 
(у широкому та вузькому значеннях). Через те, що одним з найбільш складних і суперечливих процесів у розвитку сучасного світу є соціокультурна глобалізація, яка охоплює такі сфери, як наука, освіта, культура, етика, ідеологія тощо, та породжує не тільки взаємопроникнення, але і взаємовідштовхування культур. 3 одного боку, глобалізація сприяє прискоренню соціокультурної динаміки, значному збільшенню обсягу інформації, споживаної індивідом. Вона долає політичні кордони та ідеологічні бар'єри, які здавалися непорушними протягом багатьох століть. Макдональдизація у широкому сенсі являє собою набір принципів організації діяльності, що дозволяють, керуючись чіткою схемою обмежень та правил, максимально швидко й ефективно досягати поставленої мети. Тобто це процес, під час якого принципи роботи ресторану швидкого обслуговування починають визначати практично всі сфери суспільства. Можна назвати це своєрідним спрощенням існуючої дійсності, існування за певними шаблонами, стандартами.

Ведучи мову про практики макдональдизації, які грунтуються на ряді принципів, вказаних Дж. Рітцером, слід згадати факт того, що вони ілюструють собою властивості постнекласичного світу, коли несуттєві, випадкові явища набувають характеру важливих і значущих, що забезпечують ефективність, передбачуваність, надійність тощо. Так, 3. Бауман зазначає, «що відбувається стійка та послідовна «макдональдизація» міського простору з іiі пануючою тенденцією до стандартизації та встановлення одноманітності, та чим менш передбачуваним є міське середовище, тим вищою стає цінність мікрообластей, на кшталт ресторацій MacDonald's, кафе Starbuks або закусочних Steak Hous та Pizza Hut, які приносять довгоочікуване визволення від збиваючої з толку новизни». Все це посилює дезорієнтованість мешканців та їх ідентичностей, усвідомлення як теперішнього, так і майбутнього [2].

Третім показовим моментом є виникнення гібридних форм архітектурних ландшафтів, що репрезентують собою досить дивні комбінації стилів катеринославського модерну, радянського конструктивізму, постмодернізму, хай-теку тощо. Так, іспанський письменник та філософ Ж. Субірос підкреслює, що однією з головних проблем сучасного міста $\epsilon$ те, що часто нові райони забудови задумуються й організовуються подібно до островів, які наче існують поза історією та традиційними кодами значень. І ця неадекватність більшою мірою залежить від неможливості зустрічі різних часів у певному місці. Інакшими словами, існує брак артикуляції між дуже різними досвідами різноманітних груп, що утворюють місто, між історичними відповідниками та сучасними формами, між спогадами, образами, традиційними цінностями та інноваційними проектами [10].

Візуальний та змістовний аналіз результатів комбінації різних історико-культурних традицій містобудування, проектування та урбанономії дозволив зафіксувати специфічні та типові характеристики міського простору м. Дніпра — від катеринославського модернового стилю 
до індустріального домінування, конструктивізму, постмодернізму, ефектів «макдональдизації», національного романтизму тощо. Надалі цей вектор досліджень може бути поглиблено за рахунок включення до методологічної бази аналізу принципів семіології та дискурс-аналітичної стратегії у вивченні міста.

\section{Список використаної літератури}

1. Архитектура: город для одинаковых (2011). URL: http://www.vokrugsveta.ru/ vs/article/7563/

2. Бауман 3. Город страхов, город надежд. Логос. № 3, 2008. С. 24-53.

3. Бачинська Л. Способи реалізації державно-ідеологічної сутності у радянській архітектурі 1940-х - 1950-х років. Web of Scholar, 2018. № 5(23), Vol. 1.

4. Вахштайн В. Социология архитектуры: как общество отражается в зданиях. 2019. URL: https://postnauka.ru/faq/103581.

5. Давидич Т. Соединение российских, украинских и европейских тенденций в архитектуре харьковского модерна. Архітектура, 2017. №1, с. 29-38.

6. Джекобс Д. Смерть и жизнь больших американских городов. Москва : Новое издательство, 2011.

7. Иконников А. Архитектура XX века. Утопии и реальность: Издание в двух тт. Том II / Под ред. А.Д. Кудрявцевой. Москва : Прогресс-Традиция, 2002.

8. Лотман Ю. Семиосфера. Культура и взрыв. Внутри мыслящих миров: Статьи. Исследования. Заметки. Санкт-Петербург : «Искусство-СПб», 2000.

9. Назаров М. Архитектурное пространство как социокультурный феномен Волгоград : Изд-во ФГБОУ ВПО ВолгГАСУ, 2010. С. 136.

10. Субірос Ж. Культурні стратегії та оновлення міста: досвід Барселони. Місто й оновлення. Урбаністичні студіі. Представництво Фонду ім. Гайнріха Бьолля в Україні; Редкол.: С. Шліпченко, В. Тимінський, А. Макаренко, Л. Малес, І. Тищенко. Київ, 2013. С. 360.

11. Хан-Магомедов С. Архитектура советского авангарда: В 2-кн. : Кн. 2. Социальные проблемы. Москва : Стройиздат. 2001.

12. Хан-Магомедов, С. (2006). Хрущевский утилитаризм: плюсы и минусы. Академия, 4, 17-23.

13. Хрущовки. Минуле: як французька мрія стала радянською реальністю. (2017). URL: https://ife.pravda.com.ua/culture/2017/09/27/226648/.

14. Эко, У. (2006). Отсутствующая структура. Введение в семиологию. СанктПетербург : Симпозиум.

\section{Михно Н. К. Трансформация архитектурных форм города под влиянием изменений социоисторических условий}

Основное внимание в данной статье сосредоточено на определении характера изменений архитектурных форм в городском пространстве в зависимости от движения социоисторических условий развития общества. Описана актуализачия научного интереса к изучению места и роли архитектурных объектов в плоскости модерна. Выделены основные научные векторы исследования проблемного поля сочиологии архитектуры. Подчеркнуто, что изменения, которые происходят в политическом $u$ 
культурном поле, соответственно влияют на организацию пространства города, в частности архитектурные ландиафтыл. В истории украинского обиества произошли драматические сдвиги при переходе от имперского к советскому идеологическому дискурсу современного независимого украиниуа, что соответственно повлияло на символическую маркировку пространственных явлений и развития городов. На основе предложенных У. Эко архитектурных классификационных кодов (синтаксис - код, относящийя $\kappa$ технике строительства; семантическая - артикулячиия архитектурных элементов, артикуляциия типов конструкций) и в результате проведенного авторского исследования методом визуального анализа на примере города Днепра были зафиксированы специфические и типичныле характеристики городского пространства - от Екатеринославского модернового стиля к индустриальному доминированию, конструктивизму, постмодернизму, эффектов «макдональдизации», национального романтизма и так далее.

Архитектурную форму зданий советского периода представляют «Сталинка», «Хрущзевка» и панельные жилье дома. Отмечено, что данная классификачия зданий синтагматически отражает наиболее значимые архитектурныеобъектыгорода. Значительноевниманиеуделеноособенностям производства и презентации архитектурных кодов в современном украинском городе. Отмечено, что сдвиги в организационной политике развития городского пространства, большое количество разнообразньх тенденций в архитектурных моделях, изменение социокультурных и социальноэкономических условий существования украинского обшества существенно повлияли на визуальный и символический образ украинских городов. Обрашуатся внимание на исчезновение идеологических рамок развития города и включение национально-патриотической символики и идеологических кодов в архитектурный ландшафт города. Указан отраженный в архитектурном ландшафте и обшественных пространствах тренд города «макдональдизация» (в широком и узком смысле). Записано появление гибридных форм архитектурных ландиафтов, довольно странное сочетание стилей Екатеринославского Модерна, советского конструктивизма, постмодернизма, хай-тека и так далее.

Ключевые слова: город, городское пространство, архитектурный объект, архитектурный ландиафт, архитектурная форма, визуальный код, публичное пространство.

\section{Mikhno N. Transformation of architectural forms of the city under the effect of changes in socio-historical conditions}

The main focus of this article is on determining the nature of the changes of architectural forms in the urban space depending on the movement of socio-historical conditions of development of society. Contoured actualization of scientific interest to study the place and role of architectural objects in the plane modern. Main scientific vectors the study of the problem field of sociology of architecture. Emphasized that the changes that occur in the political and cultural field, respectively, affect the organization of space, in particular architectural landscapes. In the history of the Ukrainian society has undergone dramatic shifts in the transitions from Imperial to Soviet ideological discourse of the modern independent Ukrainian, which consequently influenced the symbolic marking of spatial phenomena and urban development. Based on the proposed U. Eco architectural classification codes (syntax - code referring to the construction technique; semantic - articulation of 
architectural elements, the articulation of the types of structures) and as a result of the author's research method of visual analysis on the example of the city of Dnepr were recorded the specific and typical characteristics of urban space - from Ekaterinoslav modern style to industrial dominance, constructivism, postmodernism, the effects of "McDonaldization", national romanticism, and the like.

The architectural form of the buildings of the Soviet period is represented by "Stalinka", "Khrushchevka" and panel apartment blocks. It is noted that this classification of buildings reflects syntagmatically the most meaningful architectural objects in the city. Considerable attention is focused on the features of the production and presentation of architectural codes in the modern Ukrainian city. It is noted that the shifts in organizational policy development of urban space, a large number of diverse trends in architectural models, changing sociocultural and socioeconomic conditions of existence of the Ukrainian society significantly influenced the visual and the symbolic image of Ukrainian cities. Attention is drawn to the disappearance of the ideological frames of development of the city and incorporation of the nationalPatriotic symbolism and ideological codes in the architectural landscape of the city. Specified reflected in the architectural landscape and public spaces trend city of "macdonaldization" (in the broad and narrow senses). Recorded the emergence of hybrid forms of architectural landscapes, are quite a strange combination of styles Ekaterinoslav Moderne, Soviet constructivism, postmodernism, hi-tech etc.

Key words: city, urban space, architectural object, architectural landscape, architectural form, visual code, public space. 